\title{
Climate change and integrated analysis of mountain geomorphological systems
}

\author{
Emmanuel Reynard, Christophe Lambiel, \\ Stuart N. Lane, Lausanne
}

\section{Introduction: sediment transfers and mountain complex systems}

Quantification of the effects of climate changes upon the Earth system, both historically and over the next century, is particularly relevant today. PARRY et al. (2007), for the Intergovernmental Panel on Climate Change, make a critical observation: little work has been conducted on the expected impacts of climate change on sediment production and transfer in mountain watersheds and the subsequent sediment loads in rivers (KunDZEWICZ et al. 2007), especially in mid and low latitude mountain environments (Alcamo et al. 2007). This is despite two major concerns: (1) the dynamics of sediment delivery to and transport in mountain river systems is of crucial significance for flood risk (e.g. LANE et al. 2007); and (2) watershed sediment systems are particularly sensitive to climate change, as observed across a variety of scales from the individual basin (e.g. Rumsby \& MackLin 1994) to the regional scale (e.g. KNox 1999; WARNER 1987), especially where historical land use changes such as deforestation are important (MACKLIN \& LEWIN 2003).

Since the early 2000s, the University of Lausanne has developed a research programme concerned with environmental change in both high-mountain and arid regions (WINISTÖRFER \& REYNARD 2003). The primary geographical focus of this work has been the Val d'Hérens, a watershed of the River Rhône, Switzerland, with an altitudinal range from $4357 \mathrm{~m}$ a.s.l. (Dent Blanche) to $493 \mathrm{~m}$ a.s.l. (confluence of the Borgne river with the Rhône river), a suite of geomorphic processes (periglacial, glacial, gravitative, fluvial), and multiple influences linked to both climate changes and human impacts (e.g. hydropower plants, roads, mountain villages and tourist resorts). The catchment contains the «Maison des Alpes», a foundation that promotes the natural and cultural heritage of the Alpine region. Since 2008, the Institute of Geography of the University of Lausanne (IGUL) has worked collaboratively with this Foundation. Our aim in this paper is to conceptualise our understanding of high mountain sediment transfer systems in Alpine settings so as to identify critical research questions over the next decade for this environment. We illustrate IGUL's contribution to three elements of this work: (i) permafrost distribution and characteristics in high catchments; (ii) modelling of sediment transfers in the Borgne d'Arolla watershed, and (iii) mapping of sediment sources in mountain torrents.

\section{Conceptualisation: sediment transfers and high mountain systems}

Figure 1 synthesises the typical sediment cascade of steep Alpine catchments, showing its link to gravitational-, ice- and river-dominated sediment systems. Critical elements of the system include sources of production (e.g. freeze-thaw weathering of exposed bedrock, glacial erosion), storage (e.g. talus slopes, permafrost, moraines, debris cones, alluvial fans, gullies, river braid plains) and transfer (e.g. rock fall, solifluction and creep, englacial and superglacial transfers, rock glaciers, landslides, debris flows, fluvial river). However, these definitions are misleading because delimiting a «store» from a «transfer» is timescale dependent. For instance, over very short timescales (hours to days), a rock glacier is effectively a sediment store because its rate of sediment transfer is generally below detectable limits. However, over months to years, it may become an important sediment transfer, perhaps even a dominant one over many decades. Over very long time-scales (millennia and beyond), in tectonically and glacially high mountain environments, there may be very few true sediment stores (i.e. permanent deposition zones). The critical research question, then, is not only whether or not climate change impacts upon sediment production, but also whether or not it changes the timescales at which stores become defined as transfers, and so impacts upon sediment flux across the landscape. In addition, the ways in which different sediment transfer systems are coupled or connected impacts upon the extent to which material enters or bypasses parts of the system with much lower sediment transfer rates. Such connection is a geographical question, related to the spatial arrangement of geomorphic features within a river basin, and may have a secondary link to environmental change if such change impacts upon sediment connectivity. We know surprisingly little about this coupling in high Alpine environments (but note OtTo \& DiKAU 2004).

The system at any one time will contain the effects of a range of spatial and temporal scales. Given the system is coupled and threshold-dominated, the system is likely to be complex and nonlinear (PhILLIPS 2009) 


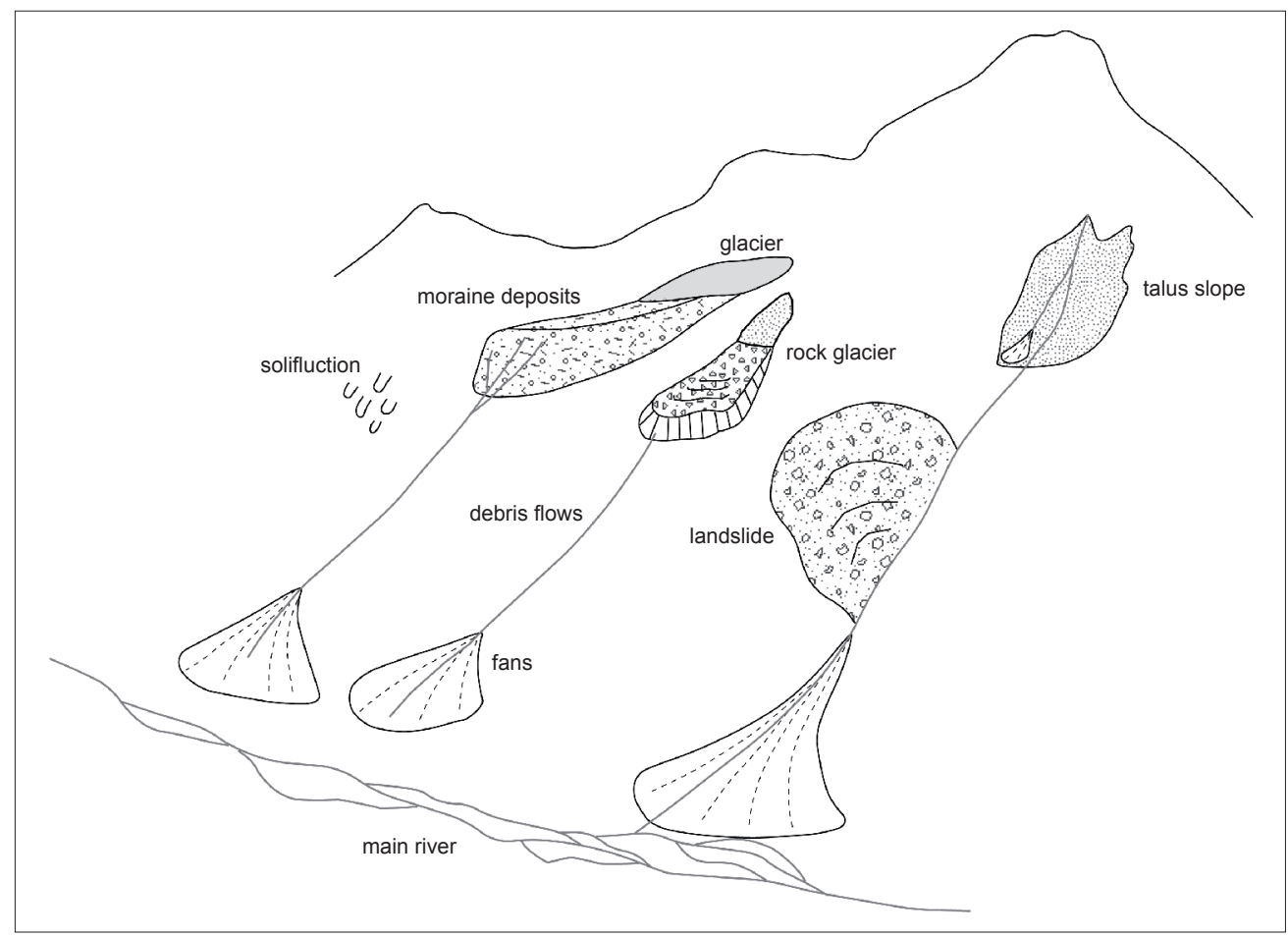

Fig. 1: Schematic representation of a typical steep alpine slope affected by various processes Schéma d'un versant alpin typique concerné par différents processus Schematische Darstellung eines typisch alpinen Berghangs und verschiedener Prozesse Graphics: C. LAMBIEL

and understanding its response to the direct effects of temperature and precipitation changes will not be easy. Yet, there are four critical reasons why these systems may be highly sensitive to rapid climate change.

First, these systems are generally out of equilibrium with current climate. Deglaciated landscapes are commonly (over-)steep, with slopes close to the threshold at which sediment transfer can begin and contain an extensive mixed mantle of glacially-derived sediments as well as sediments produced when the frost cracking window covered a greater range of landscape elevations. Continuing sediment system stability may be dependent upon a permanently or near permanentlyfrozen subsurface (e.g. JomelLi et al. 2004).

Second, sediment mobilisation and transfer requires water, both to mobilise sediment movement within the soil-sediment mantle (e.g. Dietrich et al. 1982) but also to transfer mobilised sediment (LANE et al. 2008; Legros 2002; ReID et al. 2007). Three elements of mountain systems may be of particular importance: (i) a permanently frozen subsurface layer which can impede drainage, elevating pore water pressures and encouraging soil-sediment mobilisation (e.g. BROOKS et al. 1993); (ii) a potential water supply associated with summer melt of the frozen soil-sediment at the surface; and (iii) rain-on-snow events, as the induced snow melt is equivalent in effect to an increase in rainfall intensity, which may be critical to mobilisation (e.g. MontGomery et al. 1997). The effects of possible climate warming upon permafrost decay, and drainage impedance, may be critical.

Third, mountain systems themselves also moderate synoptic meteorological conditions in ways that make the sensitivity of the sedimentary system particularly important. For instance, they may drive the rapid uplift of moist unstable air, so leading to a positive altitudinal gradient in precipitation intensity.

Finally, it is highly likely that there will be a growing 
disequilibrium between the rate of soil development and vegetation colonisation (decades to centuries) and the rate of climatic amelioration (years to decades). A number of studies (e.g. Parola \& Rossi 2008) have demonstrated that climate amelioration has resulted in an upwards migration of Alpine plant species. However, the vast majority of primary colonisers of nonvegetated hillslopes are ineffective in terms of their controls upon slope stability: it is the second and tertiary colonisers, shrubs and tree species, that are critical. These take decades to centuries to respond.

These four factors are supported by research that suggests acceleration in sediment production and transfer rates for some elements of mountain sedimentary systems. HugGel et al. (2010) report an increase in frequency of large slope failures in high mountain regions over the past 2 to 3 decades. Short duration of unusually warm events (e.g. the 2003 heatwave) seemed to be particularly important for slope failures (see also Keiler et al. 2010; Ravanel \& Deline 2011). Similarly Delaloye et al. (2008) and Roer et al. (2008) observed an acceleration of several rock glaciers in the Valais Alps since the 1990s, probably linked to permafrost warming. STOFFEL (2010) identified 62 debris flows in small, high Alpine watersheds in the period since 1863, observing that whilst advective storm events in August and September were the most important mobilisers of debris flows, changes in permafrost were exacerbating debris flow frequencies (see also MARCHI et al. 2009). These studies provide a general context for three examples that we now present from the Val d'Hérens.

\section{Three examples in the Val d'Hérens}

\subsection{Permafrost distribution and rock glacier dynamics}

The question of the reaction of mountain permafrost to global warming is still partly unresolved, not least because systematic monitoring began only recently (e.g. Harris et al. 2009). The Swiss PERMOS (Permafrost Monitoring Switzerland, www.permos.ch) network has been active since the beginning of the $21^{\text {st }}$ century with the aim of quantifying the spatial and temporal evolution of permafrost. Understanding climate change impacts needs to begin with the prior identification of spatial distribution of permanently frozen ground. This has been shown to be extremely discontinuous, due to multiple controlling factors (e.g. topographical effects, grain size, air advection, snow mantle characteristics), which can change very rapidly over a short distance (e.g. Lambiel \& Pieracci 2008). The response to climate change will be filtered by these factors both because they determine the local effects of regional climate change but also because icecemented sediments react very slowly to temperature shifts, due to latent heat exchanges connected with water phase changes. Local variability in water content may then be a critical variable. In comparison with the regional scale (e.g. the Alps), permafrost distribution and evolution at the local scale (e.g. valley slope) are much less well-known.

Discontinuity at the local-scale has been shown through a series of field investigations in the Val d'Hérens, notably the Arolla valley, which demonstrate that understanding permafrost locations and dynamics needs to be based upon an understanding of wider geomorphic controls. LAMBIEL \& PIERACCI (2008) mapped the distribution and internal structure of permafrost for 7 talus slopes. Two of these were located on the west facing valley side between c. $2500 \mathrm{~m}$ a.s.l and $3300 \mathrm{~m}$ a.s.l. This is a geomorphically-active zone (e.g. permafrost creep, rock falls, debris flows) with some major landform units (e.g. active rock glaciers, large rockslides, morainic bastions, talus slopes) in a steep valley-side setting (Fig. 2). Although measurements (1D geoelectrical coupled to ground-surface temperature) revealed that frozen ground is present in the lower part of the Tsarmine talus slope, its presence is much less certain upslope (LAMBIEL et al. 2004). This contrast between lower and upper talus slopes was encountered in most of the investigated sites, which permitted us to propose a conceptual model for the permafrost distribution within mountain talus slopes (Lambiel \& Pieracci 2008). The model was then confirmed by $2 \mathrm{D}$ geophysical measurements and borehole logging within several selected landforms in the area by ScApozza et al. (2011).

Investigation of moraine deposits, in particular the glacier forefield of the Tsarmine glacier (Fig. 2; LAMBIEL et al. 2004), revealed the critical role of debris cover in preserving permanently frozen conditions. As confirmed by other investigations (e.g. REYNARD et al. 2003), debris-covered ice was found in the main part of the proglacial margin. Post Little Ice Age glacier recession has been limited by rock fall activity from overhanging rock faces, which provides a continuous and thick cover of debris on the glacier. Possible permafrost conditions may also favour the preservation of ground ice at shallow depth. However, the steep morainic bastion was found to be permafrost free, and this may be critical for debris flow initiation. These studies show that understanding the spatially discontinuous nature of permafrost is only possible if the effects of geomorphic setting are considered. The local scale heterogeneity in permafrost is likely to be extremely challenging to model, even before its possible effects on sediment transfer and associated climate change impacts are considered.

Work on rock glaciers in the valley confirms another observation that there appears to be a change in the 


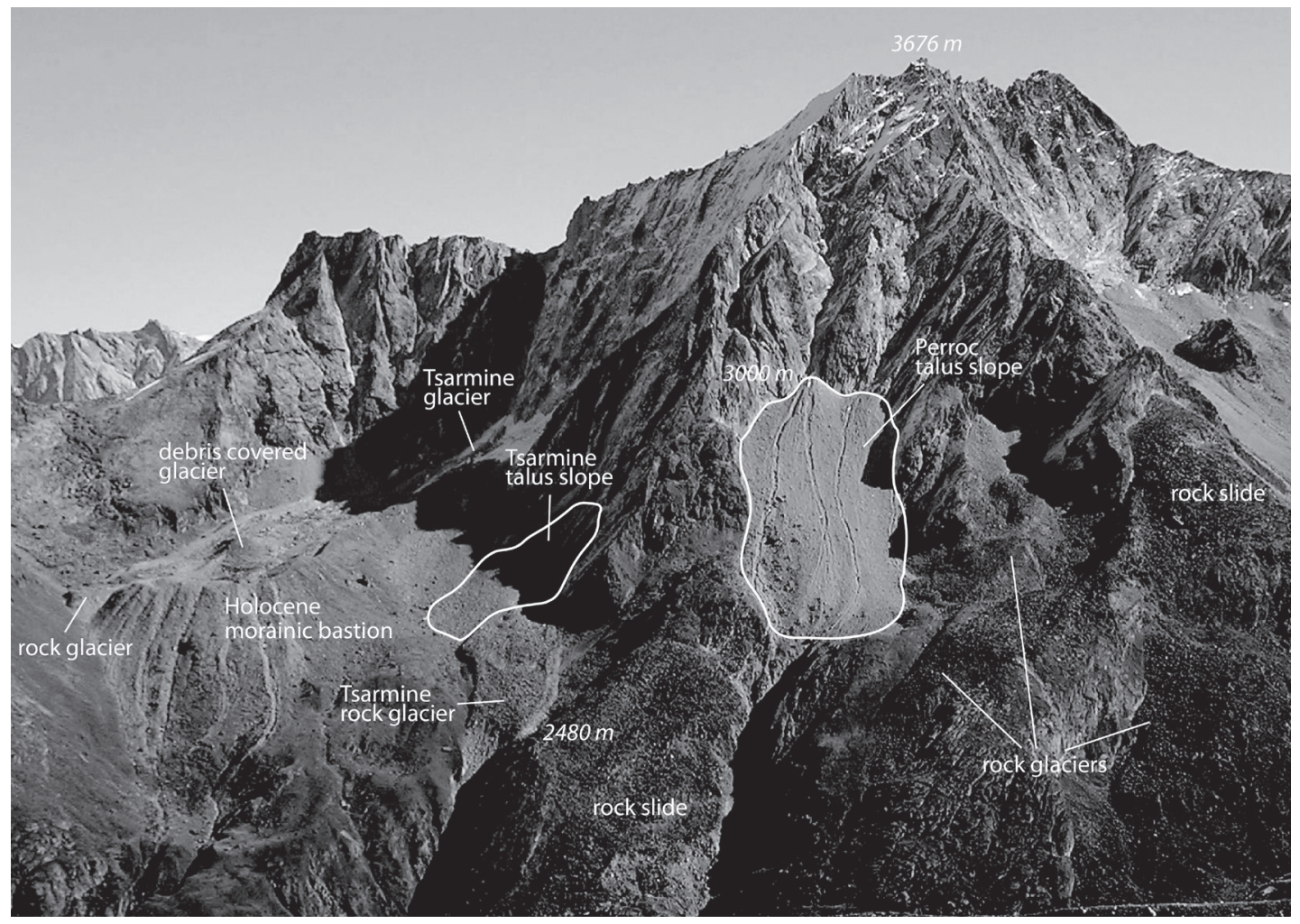

Fig. 2: Front view of the Tsarmine research area on the right hand side of Arolla valley Vue de la région de Tsarmine, sur la rive droite du Val d'Arolla Frontalansicht des Tsarmine Untersuchungsgebiets auf der rechten Seite des Arolla Tals Photo: R. Delaloye, graphics: C. LAmbiel

rate of transfer of sediment through these systems. Work in collaboration with the University of Fribourg has shown that the Tsarmine rock glacier has annually-averaged flow velocities greater than $2.5 \mathrm{~m}$ p.a. (LAmBIEL et al. 2008). Analysis of aerial photographs suggests that velocities have increased over recent decades and this has been linked to the effects of climate warming upon permafrost (e.g. Delaloye et al. 2010). The photographs revealed also that the front moved about 15 m downslope between 1983 and 1999 (LAMBIEL 2006). Daily pictures recorded by a webcam since autumn 2009 show that rock falls from the top of the rock glacier front are very frequent and lead to significant sediment storage in the connected gully. This is an example of the critical effect of coupling between elements of the sedimentary system and is important in explaining why the Tsarmine rock glacier plays a major role in the sediment cascade of the slope. The net consequence of increasing activity of the rock gla- cier is thus a speed up of the sediment transfer towards the valley floor.

\subsection{Sediment transfer in Alpine river systems: the Borgne d'Arolla}

Fluvial geomorphology has traditionally suffered from one critical problem: the inability to look beyond the river channel-floodplain system. However, in lower order drainage basins, the coupling between the river and its hillslopes becomes as, if not more, important than the discharge of water and sediment from upstream river reaches. Indeed, LANE et al. (1996) found from repeat survey of the proglacial braided river of the Haut Glacier d'Arolla that whilst the tendency to erosion was broadly hydraulically controlled, and linked to the rising limb of the flow hydrograph, deposition was largely independent of hydraulic factors and related more to the rate of sediment delivery from upstream. 

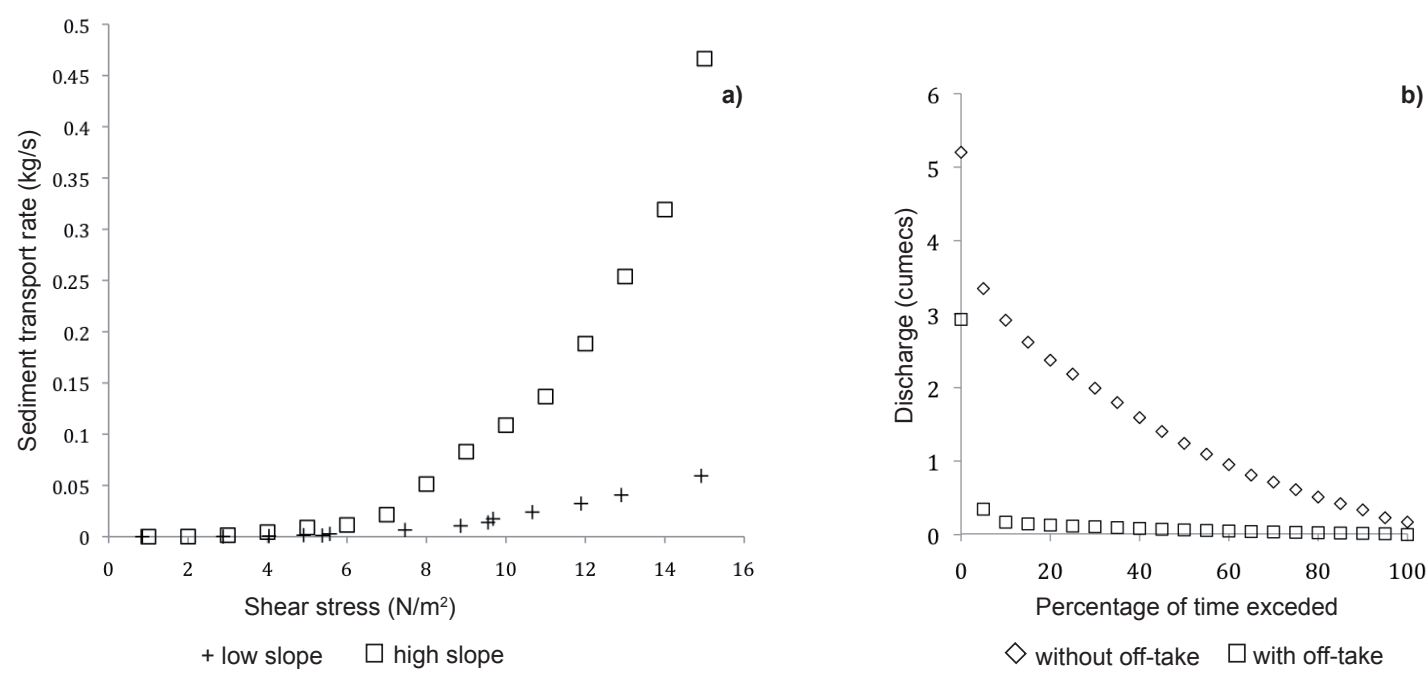

Fig. 3. Sediment transport rate dependant on shear stress (a) and flow duration with and without hydroelectric power offtake (b) for the Borgne d'Arolla

Variation de la capacité de transport sédimentaire en fonction des contraintes de cisaillement (a) et de la durée du débit avec et sans prélèvement hydroélectrique (b) pour la Borgne d'Arolla

Sedimenttransportraten in Abhängigkeit von der Schubspannung (a) und Fliessdauer mit und ohne hydroelektrischer Entnahme (b) für die Borgne d'Arolla

Graphics: S.N. LANE.

With information on the river channel boundary (shape and grain-size), some estimation of the water surface and friction slopes, and the discharge of water, it is possible to model sediment transport capacity taking into account energy partitioning linked to both boundary grain-size and cross-section shape. Figure 3 shows application of the WILCOCK \& Crowe (2003) gravel bedload transport model to data from the Borgne d'Arolla. This emphasises that sediment transport is threshold-dominated, here increasing markedly at shear stress values greater than $6 \mathrm{Nm}^{-2}$ (Fig. 3a, high slope). This is equivalent to a discharge of approximately $1.0 \mathrm{~m}^{3} \mathrm{~s}^{-1}$. Figure $3 \mathrm{~b}$ shows a modelled flow duration curve for the same stream without accounting for any off-take of water linked to hydroelectric power. In theory, whether or not climate change related hydrological responses then propagate into sediment transport capacity changes depends upon how the shape of Figure $3 \mathrm{~b}$ changes, and in particular whether or not the percentage of time that flows exceed $1 \mathrm{~m}^{3} \mathrm{~s}^{-1}$ changes. But, more importantly, Figure $3 \mathrm{~b}$ shows that the real driver of this system is unlikely to be the direct effects of climate change upon catchment hydrology as long as there is a significant off take of water for hydroelectric power.
Unfortunately, the estimation of possible changes in sediment transport capacity in these systems is likely to be the most straightforward element of the question of how climate change might impact upon high Alpine fluvial systems. It is much more difficult to determine how sediment supply will change, an influence that is important for two reasons. First, changes in sediment transport capacity will only be realised as changes in sediment transport itself for as long as sediment delivery matches or exceeds the increased capacity. Thus, consideration has to be given to wider changes in sediment delivery, a property of the wider catchment system. Second, sediment transport capacity will also be driven by feedbacks linked to the morphological response of the river, especially in the presence of aggradation: aggrading systems in high mountain systems tend to become multithread as long as there is sufficient accommodation space. Sediment delivery also tends to be localised (Fig. 1), often linked to fan systems, which can significantly reduce transport capacity (see Fig. 3a, which shows the change in sediment transport capacity linked to a typical fan-related reduction in valley floodplain slope). The resultant repartitioning of energy tends to reduce transport capacity, so exasperating aggradation. 
Thus, understanding the effects of climate change upon high Alpine stream systems is not just about understanding the direct effects of climate change upon catchment hydrology. The kinds of climate impacts described in the previous section, linked to wider catchment processes, may be critical. Likewise, the effects of human impacts in highly regulated catchment systems cannot be ignored.

\subsection{Process-oriented geomorphological mapping}

Debris flows are one of the most important vectors of sediment transfer in mountainous areas (STERLING \& SLAYMAKER 2007). As for rivers, most of the research has focused on hydrological processes and on the reconstruction of sedimentary activity on alluvial fans. However, knowledge of potential sediment sources in the upper catchments, in terms of distribution, propensity to connect and potentially mobilisable volumes, is of critical importance, both for existing watershed management and for understanding short to medium term climate change impacts. Geomorphological mapping has the potential to help here, but the majority of geomorphological mapping systems developed until now have focused on morphogenetic classifications, limited in terms of process analysis because they do not consider sufficiently process dynamics (THELER et al. 2008, 2010). But, there is also an increasing opportunity to harness geomorphological mapping in sediment system analysis because the traditionally time consuming and challenging (e.g. steep catchments) classical methods can now be supported by developments in Geographical Information Systems (GIS) (Gustavsson et al. 2006).

Theler et al. $(2008,2010)$ combine field mapping and GIS based terrain analysis and aim to estimate both the processes concerned with triggering of debris-flows and potentially mobilisable volumes. The mapping system is based on two matrixes. The first one combines slope gradients and vegetation cover. The second considers connectivity with the main channel and possible transfer processes. Each subcatchment is then characterised through the system so as to identify those most likely to be contributing to sediment production and transfer and to determine those areas within the catchment needing more detailed volume calculations and possibly monitoring systems. The method was tested in two torrential systems of the Rhône river catchment and is now used for defining which torrents in the Val d'Hérens (Fig. 4) need further attention. Combination of GIS with supporting field analysis has the potential to provide the critical boundary conditions necessary for quantification of potentially mobilisable volumes using other process analyses, something that is critical for both hazard prevention and risk management and understanding the effects of future climates. The next goal is to model potential volumes and their linkages with river system activity.

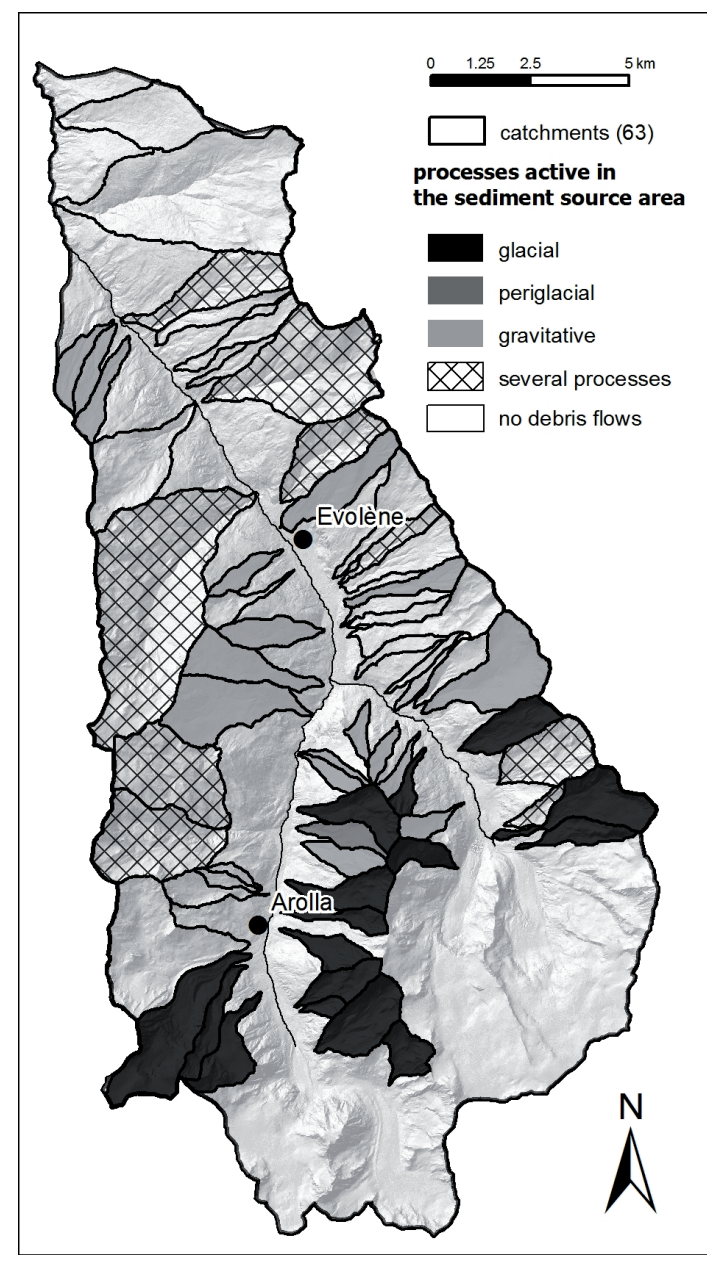

Fig. 4: Catchments prone to debris-flow activity in the Hérens valley

Carte des bassins versants sujets à des laves torrentielles dans le val d'Hérens

Murgang-anfällige Einzugsgebiete im Hérens Tal

Cartography: B. MAILlaRD

\section{Conclusion}

The above examples show that current geomorphic process activity and the modelling of future changes must combine: (i) characterisation of the current geomorphological system (e.g. through geomorphological mapping and intensive field survey); (ii) quantification of process activity (e.g. through measurements and monitoring); (iii) mathematical modelling of current processes and feedbacks in response to future forcing. They also indicate why high mountain sedimen- 
tary systems may be particularly sensitive to climate change and so need significant research attention. Whilst recent work suggests a speeding up of individual elements of the sediment transfer process, there also remains a set of critical and unresolved questions, which, in turn, shape the necessary focus of Swiss contributions to geomorphic research in high mountain environments. In this onclusion, we identify five principles that we believe need to underpin this focus.

First, understanding future climate effects requires us to consider mountain catchments as holistic cryospheric-hydrologic-geomorphic systems. Geomorphic research in high mountain environments has tended to focus upon singular elements of the sediment transfer system (e.g. landslides, rock glaciers, debris flows). Yet, it is the connections between them that will determine whether or not the total basinscale sediment flux is responding to climate change, and these have been less well-considered.

Second, our examples demonstrate the importance of intensive survey at the scale of small catchments coupled to methods of generalisation to the regional scale (e.g. Switzerland, Alps) through field-informed modelling. Whilst studies have sought to develop regional correlations between temperature records and changing sediment transfer activity, such correlations overlook the mediating effects of endogenous environmental processes, such as those that control the annual and local depth of penetration of the summer thaw of winter-frozen ground, leading to possible non-linear responses to temperature rise. A more sophisticated attempt to measure and to model the ambient environmental conditions that are associated with any reconstructed changes is required that captures more sensitively the critical role played by local forcing and feedbacks.

Third, we emphasise that fluvial research in these systems needs to consider more than just the hydrological system but also the links with other geomorphic subsystems (e.g. hillslopes, rock glaciers, landslides). In particular, very few studies have explored the extent to which changing sediment transfer at the hillslope scale can be detected in changing river response and vice versa (SchwAB et al. 2008 is an exception).

Fourth, climate change is not the only factor that will influence the intensity and spatial distribution of mountain processes. Anthropogenic factors will also impact on the sediment transfer system. Efforts must be made to delineate human-natural processes interactions, as well as positive/negative feedback loops.

Finally, almost all of the above studies have focused upon the period between the end of the Little Ice Age (c. 1860 in the European Alps) and present, and most commonly upon the period associated with the aerial photographic record (post 1940s). Whilst the latter period allows for the most detailed reconstructions, there is also the need to attempt to quantify changing activity over much longer timescales, extending through to the last millennium. Given recent work that has been done at a European level, we now have a very good understanding, through reconstruction, of climatic variability over the last millennium (e.g. Holzhauser et al.2005). A challenge is now to reconstruct levels of sediment dynamics over this longer timescale in high mountain settings.

It is the aim of the project «Val d'Hérens», at the University of Lausanne, to apply these five principles to a watershed of regional importance, in order to model future changes with which Alpine societies will have to deal in the future decades.

\section{References}

Alcamo, J., Moreno, J.M., Nováky, B., Bindi, M., Corobov, R., Devoy, R.J.N., Giannakopoulos, C., Martin, E., Olesen, J.E. \& A. Shvidenko (2007): Europe. - In: Parry, M.L., Canziani, O.F., Palutikof, J.P., vAN DER Linden, P.J. \& C.E. Hanson (eds): Climate change 2007: impacts, adaptation and vulnerability. Contribution of Working Group II to the Fourth Assessment Report of the Intergovernmental Panel on Climate Change. - Cambridge: Cambridge University Press: 541-580.

Brooks, S.M., Richards, K.S. \& M.G. Anderson (1993): Approaches to the study of hillslope development due to mass movement. - In: Progress in Physical Geography 17, 1:32-49.

Delaloye, R., Strozzi, T., Lambiel, C. \& E. PerruCHOUD (2008): Landslide-like development of rockglaciers detected with ERS-1/2 SAR interferometry. - In: Proceedings ESA FRINGE Symposium, Frascati, Italy, 26-30 November 2007.

Delaloye, R., Lambiel, C. \& I. Gärtner-Roer (2010): Overview of rock glacier kinematics research in the Swiss Alps. Seasonal rhythm, interannual variations and trends over several decades. - In: Geographica Helvetica 65, 2: 135-145.

Dietrich, W.E., Dunne, T., Humphrey, N.F. \& L.M. REID (1982): Construction of sediment budgets for drainage basins. - In: SwANSON, F.J., JANDA, R.J., Dunne, T. \& D.N. Swanston (eds): Forested drainage basins. - Washington, D.C.: U.S. Department of Agriculture: 5-23.

Gustavsson, M., Kolstrup, E. \& A.C. Seijmonsbergen (2006): A new symbol-and-GIS based detailed geomorphological mapping system: renewal of a scientific discipline for understanding landscape development. - In: Geomorphology 77, 1-2: 90-111. 
Harris, C., Arenson, L.U., Christiansen, H.H., Etzelmüller, B., Frauenfelder, R., Gruber, S., HaeBerli, W., Hauck, C., Hölzle, M., Humlum, O., IsaKSen, K., KäÄв, A., Kern-Lütschg, M.A., Lehning, M., Matsuoka, N., Murton, J.B., Nötzli, J., Phillips, M., Ross, N. \& M. SEPpÄLÄ (2009): Permafrost and climate in Europe: monitoring and modelling thermal, geomorphological and geotechnical responses. - In: Earth Science Reviews 92, 3-4: 117-171.

Holzhauser, H., Magny, M. \& H.J. ZumbüHL (2005): Glacier and lake-level variations in west-central Europe over the last 3500 years. - In: The Holocene 15, 6: 789-801.

Huggel, C., Salzmann, N., Allen, S., Caplan-AuerBACH, J., Fischer, L., HAEberli, W., LARSEN, C., SchneiDER, D. \& R. Wessels (2010): Recent and future warm extreme events and high-mountain slope stability. - In: Philosophical Transactions of the Royal Society A 368, 1919: 2435-2459.

Jomelli, V., Pech, V.P., Chochillon, C. \& D. BrunSTEIN (2004): Geomorphic variations of debris flows and recent climatic change in the French Alps. - In: Climatic Change 64, 1-2: 77-102.

Keiler, M., Knight, J. \& S. Harrison (2010): Climate change and geomorphological hazards in the eastern European Alps. - In: Philosophical Transactions of the Royal Society A 368, 1919: 2461-2479.

Knox, J.C. (1999): Long-term episodic changes in magnitudes and frequencies of floods in the upper Mississippi river valley. - In: Brown, A.G. \& T.A Quine (eds): Fluvial processes and environmental change. Chichester: Wiley: 255-282.

Kundzewicz, Z.W., Mata, L.J., Arnell, N.W., Döll, P., Kabat, P., Jiménez, B., Miller, K.A., Oki, T., Sen, Z. \& I.A. Shiklomanov (2007): Freshwater resources and their management. - In: PARry, M.L., CANZIANI, O.F., Palutikof, J.P., van der Linden, P.J. \& C.E. Hanson (eds): Climate change 2007: impacts, adaptation and vulnerability. Contribution of Working Group II to the Fourth Assessment Report of the Intergovernmental Panel on Climate Change. - Cambridge: Cambridge University Press: 173-210.

Lambiel, C., Reynard, E., Cheseaux, G. \& R. Lugon (2004): Distribution du pergélisol dans un versant instable, le cas de Tsarmine (Arolla, Evolène, VS). In: Bulletin de la Murithienne 122: 89-102.

LAMBIEL, C. (2006): Le pergélisol dans les terrains sédimentaires à forte déclivité: distribution, régime thermique et instabilités. - Travaux et Recherches 33, Thèse, Institut de Géographie, Université de Lausanne. LAmbiel, C. \& K. Pieracci (2008): Permafrost distribution in talus slopes located within the alpine periglacial belt (Swiss Alps). - In: Permafrost and Periglacial Processes 19, 3: 293-304.

Lambiel, C., Delaloye, R., Strozzi, T., Lugon, R. \& H. RAETZO (2008): ERS InSAR for detecting the rock glacier activity. - In: Proceedings of the $9^{\text {th }}$ International
Conference on Permafrost, Fairbanks, June 29-July 3, 2008: 1019-1025.

LANE, S.N., Richards, K.S. \& J.H. Chandler (1996): Discharge and sediment supply controls on erosion and deposition in a dynamic alluvial channel. - In: Geomorphology 15, 1: 1-15.

Lane, S.N., TAYefi, V., Reid, S.C., Yu, D. \& R.J. Hardy (2007): Interactions between sediment delivery, channel change, climate change and flood risk in a temperate upland environment. - In: Earth Surface Processes and Landforms 32, 3: 429-446.

Lane, S.N., ReId, S.C., TAYEFI, V., Yu, D. \& R.J. Hardy (2008): Reconceptualising coarse sediment problems in river catchments as catchment-scale and diffuse. In: Geomorphology 98, 3-4: 227-249.

Legros, F. (2002): The mobility of long-runout landslides. - In: Geology 63, 3: 301-331.

Macklin, M.G. \& J. LewIN (2003): River sediments, great floods and centennial-scale Holocene climate change. - In: Journal of Quaternary Science 18, 2: 101105.

Marchi, L., Chiarle, M. \& G. Mortara (2009): Climate changes and debris flows in periglacial areas in the Italian Alps. - In: TAniguchi, M., Burnett, W.C., FukUSHIma, Y., Haigh, M. \& Y. UmeZaWA (eds): From headwaters to the ocean: hydrological changes and watershed management. - Leiden: CRC Press: 111-115.

Montgomery, D.R., Dietrich, W.E., Torres, R., Anderson, S.P., Heffner, J.T. \& K. Loague (1997): Hydrologic response of a steep unchanneled valley to natural and applied rainfall. - In: Water Resources Research 33, 1: 91-109.

Otто, J.C. \& R. Dikau (2004): Geomorphologic system analysis of a high mountain valley in the Swiss Alps. In: Zeitschrift für Geomorphologie N.F. 48, 3: 323-341. Parola, G. \& G. Rossi (2008): Upward migration of vascular plants following a climate warming trend in the Alps. - In: Basic and Applied Ecology 9, 2: 100-107. Parry, M.L., Canziani, O.F., Palutikof, J.P., van DER Linden, P.J. \& C.E. Hanson (eds) (2007): Climate change 2007: impacts, adaptation and vulnerability. Contribution of Working Group II to the Fourth Assessment Report of the Intergovernmental Panel on Climate Change. - Cambridge: Cambridge University Press.

Phillips, J.D. (2009): Changes, perturbations, and responses in geomorphic systems. - In: Progress in Physical Geography 33, 1: 17-30.

RAVANEL, L. \& P. Deline (2011): Climate influence on rockfalls in high-Alpine steep rockwalls: the north side of the Aiguilles de Chamonix (Mont Blanc massif) since the end of the «Little Ice Age». - In: The Holocene 21, 2: 357-365.

Reid, S.C., Lane, S.N., Berney, J.M. \& J. Holden (2007): The timing and magnitude of coarse sediment transport events within an upland gravel-bed river. In: Geomorphology 83, 1-2: 152-182. 
Reynard, E., Lambiel, C., Delaloye, R., Devaud, G., Baron, L., Chapellier, D., Marescot, L. \& R. Monnet (2003): Glacier/permafrost relationships in forefields of small glaciers (Swiss Alps). - In: Proceedings of the $8^{\text {th }}$ International Conference on Permafrost, Zurich, July 21-25, 2003: 947-952.

Roer, I., Avian, M., Delaloye, R., Lambiel, C., HaeBerli, W., KäÄв, A. \& V. Kaufmann (2008): Observations and considerations on collapsing active rockglaciers in the Alps. - In: Proceedings of the $9^{\text {th }}$ International Conference on Permafrost, Fairbanks, June 29-July 3, 2008: 1505-1510.

Rumsby, B.T. \& M.G. Macklin (1994): Channel and floodplain response to recent abrupt climate change: the Tyne basin, Northern England. - In: Earth Surface Processes and Landforms 19, 6: 489-515.

Scapozza, C., Lambiel, C., Baron, L., Marescot, L. \& E. REYNARD (2011): Internal structure and permafrost distribution in two alpine periglacial talus slopes, Valais, Swiss Alps. - In: Geomorphology 132, 3-4: 208-221.

Schwab, M., Rieke-Zapp, D., Schneider, H., Liniger, M. \& F. Schlunegger (2008): Landsliding and sediment flux in the Central Swiss Alps: a photogrammetric study of the Schimbrig landslide, Entlebuch. - In: Geomorphology 97, 3-4: 392-406.

Sterling, S. \& O. Slaymaker (2007): Lithologic control of debris torrent occurrence. - In: Geomorphology 86, 3-4: 307-319.

Stoffel, M. (2010): Magnitude-frequency relationships of debris flows - a case study based on field surveys and tree-ring records. - In: Geomorphology 116, 1-2: 67-76.

Theler, D., Reynard, E. \& E. Bardou (2008): Assessing sediment dynamics from geomorphological maps: Bruchi torrential system, Swiss Alps. - In: Journal of Maps 4, 1: 277-289.

Theler, D., Reynard, E., Lambiel, C. \& E. Bardou (2010): The contribution of geomorphological mapping to sediment transfer evaluation in small alpine catchments. - In: Geomorphology 124, 3-4: 113-123.

WARNER, R.F. (1987): Spatial adjustments to temporal variations in flood regime in some Australian rivers. In: RichARDS, K.S. (ed.): River channels - environment and process. - Oxford: Blackwell: 14-40.

Wilcock, P.R. \& J.C. Crowe (2003): Surface-based transport model for mixed-size sediment. - In: ASCE Journal of Hydraulic Engineering 129, 2: 120-128. Winistörfer, J. \& E. ReynARD (2003): Transformation of fragile environments in the Alps and in the Sahel. In: Geographica Helvetica 58, 3: 267-273.

\section{Abstract: Climate change and integrated analysis of mountain geomorphological systems}

This article addresses the sensitivity of high mountain geomorphic systems to climate change. It describes the challenge faced by geomorphologists to model the functioning of such systems in the future, taking into account the complex interaction between various processes, and the impacts of climatic-driven and humandriven factors. By means of three examples from different environments (permafrost areas, rivers and debris torrents), and employing different methodological approaches (field survey, mapping, modelling), the authors show that modelling of mountain geomorphic systems in the future needs to combine detailed research at a local scale (monitoring, measurements) with a modelling that takes into account the complex relationships between climatic, hydrologic, geomorphic and human subsystems.

Keywords: climate change, high mountain regions, geomorphic systems, modelling, sediment transfer

\section{Résumé: Changements climatiques et analyse intégrée} des systèmes géomorphologiques de montagne

Cet article traite de la sensibilité des systèmes géomorphologiques de montagne face aux changements climatiques. L'enjeu, pour les géomorphologues, consiste à être capables de modéliser le fonctionnement de ces systèmes complexes dans le futur, en prenant en compte les interactions complexes entre différents processus, ainsi que les impacts autant des changements climatiques que des facteurs anthropiques. Sur la base de trois exemples de recherches menées dans des environnements différents (zones à permafrost, rivières et systèmes torrentiels), en utilisant des approches méthodologiques variées (prospection de terrain, cartographie, modélisation), les auteurs montrent que la modélisation des systèmes géomorphologiques de montagne nécessite la combinaison d'études intensives de terrain à l'échelle locale (monitorage, mesures) et le développement de modélisations qui tiennent compte des relations complexes existant entre les sous-systèmes climatique, hydrologique, géomorphologique et humain.

Mots-clés: changements climatiques, haute montagne, systèmes géomorphologiques, modélisation, transfert sédimentaire

\section{Zusammenfassung: Klimaveränderungen und integrierte} Analyse der geomorphologischen Gebirgssysteme

Der hier präsentierte Artikel befasst sich mit der Sensibilität von geomorphologischen Hochgebirgssystemen gegenüber möglichen Klimaveränderungen. Die Herausforderung für Geomorphologen besteht vor allem in der Zukunftsmodellierung eines solchen Systems, welches die komplexen Wechselwirkungen zwischen mehreren Prozessen sowie die Auswirkungen von Klimawandel und menschlichem Einfluss berücksichtigt. Anhand dreier verschiedener Beispiele (PermafrostGebiet, Flusssystem und Wildbachsystem) und unterschiedlicher methodologischer Herangehensweisen 
(Feldstudie, Kartierung und Modellierung) zeigen die Autoren, dass die Zukunftsmodellierung von geomorphologischen Gebirgssystemen eine Kombination von intensiv erhobenen Felddaten auf lokaler Skala (Monitoring, Messungen) und die Modellierung der komplexen Wechselwirkungen zwischen Klima, Hydrologie, Geomorphologie und menschlichem Eingreifen erfordert.

Schlüsselwörter: Klimaveränderungen, Hochgebirge, geomorphologische Systeme, Modellierung, Sedimenttransport

Prof. Dr. Emmanuel Reynard, Dr. Christophe Lambiel, Prof. Dr. Stuart N. Lane, Institut de Géographie, Université de Lausanne, Quartier Dorigny, Bâtiment Anthropole, CH-1015 Lausanne, Switzerland.

e-mail:

Emmanuel.Reynard@unil.ch

Christophe.Lambiel@unil.ch

Stuart.Lane@unil.ch

Manuskripteingang/received/manuscrit reçu le 31.8.2011

Annahme zum Druck/accepted for publication/accepté pour publication: 23.4 .2012 